\title{
THE RELATIONSHIP BETWEEN POWERS OF EVIL AND IDOLS IN 1 CORINTHIANS 8:4-5 AND 10:18-22 IN THE CONTEXT OF THE PAULINE CORPUS AND EARLY JUDAISM ${ }^{1}$
}

\author{
Rohintan Keki Mody
}

This thesis about the relationship between powers of evil and idols in 1 Corinthians 8:4-5 and 10:18-22 proposes a 'co-optative view' that in these passages evil powers are personal supernatural evil beings. For Paul, idols are the spiritually unreal cult images of the pagan gods and, in some cases, are also the gods as conceived by pagans, who are merely imaginary and fictitious (i.e. Zeus, Sarapis, etc. do not exist).

The relationship between daimonia and idols has three inter-locking aspects. First, the daimonia are powerful and enslave humanity through their inner sinful inclination into idolatry. By doing the will of the daimonia, idolaters serve them. Secondly, the daimonia deceive humanity into sacrifices to idols. The daimonia inspire idolatry, and possibly change their forms into the pagan gods. Thirdly, the daimonia 'stand behind' the idols and co-opt the sacrifices consciously intended for the idols, and so idolaters come under the sphere of power/ influence of the daimonia.

Paul's views about daimonia being personal supernatural evil beings, the spiritual lifelessness of idols, and the 'co-optative' nature of the relationship between daimonia and idol is continuous with certain views attested in early Judaism (as found in Deut. 32, 1 Enoch, Jubilees, and Revelation). Where Paul does redefine his Jewish heritage is in seeing the holy opponent of the daimonia and idols as being Christ 'the Lord' and in exhorting the Church to express exclusive loyalty to him.

1 Rohintan Keki Mody, 'The Relationship between Powers of Evil and Idols in 1 Corinthians 8:4-5 and 10:18-22 in the Context of the Pauline Corpus and Early Judaism' (PhD Dissertation, King's College, University of Aberdeen, 2008). Supervisors: Dr Simon Gathercole and Dr Jutta Leonhardt-Balzer. 
The introduction presents three different scholarly views with reference to Paul's view of evil powers and idols: the 'identification' view (where evil powers and idols are identified with one another); the 'distinct entities in association' view (evil powers and idols are distinct entities in an arm's length relationship with one another); and the 'undefined relationship' view (where the nature of the relationship between evil powers and idols is not delineated). It proposes the key question to be answered: How does Paul see the relationship between powers of evil and idols? It then puts forward a method: focusing on passages from early Jewish texts that relate to powers of evil and idols before examining 1 Corinthians 8:4-5 and 10:18-22.

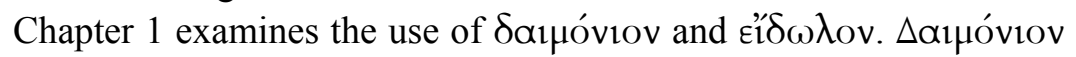
denotes something that mediates between the supernatural and natural worlds, and refers in OG Psalm 90(91); Isaiah 13; 34 to a 'supernatural power' causing harm or inhabiting ruined places and, in Tobit and Luke 4:31-37, it is developed to refer to a 'personal supernatural evil being'. E' $\delta \omega \lambda$ ov denotes something that appears real but is in fact insubstantial. It is developed to refer to the spiritual unreality of the pagan god itself in some passages in the OG (1 Chron. 16:25f.; $1 \mathrm{Kgdms}$ (1 Sam.) 17:43; Jer. 14:22) as well as to a cult image. Hence $\varepsilon \neq \delta \omega \lambda \alpha$ deceive pagans; they appear to be gods but in reality they are false and lack spiritual reality.

Chapter 2 argues that in Deuteronomy 32 the relationship between supernatural powers and idols could be characterized as that between two distinct entities. In Deuteronomy 32 daimonia are powerful personal beings with the capacity for thought and relationships who are the supernatural rulers over the pagan nations. The idols are the spiritually unreal and lifeless cult images of pagan gods. The daimonia 'stand behind' idols and co-opt and appropriate the sacrifices intended for the idols. The sacrifices to the idols of the nations are the means for Israel coming under the sphere of influence of the daimonia.

In Psalm 105(106) the daimonia are associated with spirits of the dead and, possibly, underworld Canaanite deities. Cult images may depict underworld deities and the daimonia and cult images may both be associated with underworld powers. Isaiah 65 probably does not have any relationship between daimonia and idols, but, in verse 3 , daimonia probably refers to dead rulers. In verse 11 , daimōn is used to refer to the pagan deity, the Agathos Daimōn. Zechariah 13:2 records a relationship between an evil power (the unclean spirit), idols, and false 
prophets who may attempt to deceive Israel into idolatry. Psalm 95(96) states that the pagan gods are daimonia (minor supernatural beings).

Chapter 3 examines passages in 1 Enoch, Jubilees, L.A.B., and Revelation where there is a development of the relationship between evil powers and idols. In these passages, two entities are in view. The first entity is evil powers - personal supernatural evil beings, including the spirits of the dead giants in 1 Enoch and Jubilees. The second entity is that of lifeless and powerless pagan cult images. The relationship between evil powers and idols can be conceived as having three aspects. The evil powers are powerful and they may impose idolatry as a form of bondage. Secondly, the evil powers deceive people into the worship of spiritually lifeless idols (especially in 1 Enoch 19 and Jubilees), and thirdly, the evil powers 'standing behind' idols and coopt the service intended for idols (especially in 1 Enoch 99, Jubilees, and Revelation). The act of sacrifice/worship/homage of idols is the key act by which evil powers are related to idols and are able to co-opt or divert what is intended for idols so that idolaters serve daimonia by coming into the sphere of power of evil powers. Ultimately, evil powers are served through cultic service because idolaters through their inner sinful inclination act according to the will of evil powers. In the texts examined in this chapter there is a conceptual development from the OG texts examined in chapters 1 and 2: the supernatural powers are clearly evil (opposed to God's will).

Chapter 4 examines Paul's use of eí $\delta \omega \lambda$ ov (1 Cor. 8:4, 7; 10:19; 12:2; 2 Cor. 6:16; 1 Thess. 1:9) and the concept of idolatry in Romans 1:18-32; 1 Corinthians 10:18-20a. It concluded that Paul uses عiß $\delta \lambda_{0}$ in the following ways: of a physical cultic image/representation of a pagan god; a cult image merely of gold, silver, wood, stone, metal, which Paul regards as spiritually vain and lifeless. In 1 Corinthians 8:4, 7 Ei $\delta \omega \lambda$ ov is used of the associated pagan god itself, thought by pagans to be living and spiritually real but understood by Paul to be a fiction and non-existent. This means first, that the cultic image is not to be seen as an extension of the divine presence or as inhabited by a god, but is devoid of spiritual life, being merely a lifeless physical object. Secondly, the myths and beliefs in the pagan gods (as portrayed in Homer and Hesiod) are false. These pagan gods (Zeus, Isis, etc.) have no life and therefore are merely imaginary. Any claim to truth purported to come from these pagan gods either through the physical image or through the god itself in the spiritual realm is a falsehood. 
This twofold Pauline usage is continuous with the Jewish texts examined in chapter 1 (especially 1 Chron. 16:26 and Deut. 32:21). In Romans 1 Paul reveals his abhorrence of idolatry as the universal cardinal sin of humanity. In 1 Corinthians 10:18-20a the idolatry of historical Israel is probably in view, and Paul uses the example of historical Israel to warn the church to avoid idolatry.

Chapter 5 discusses evil powers in 1 Corinthians 8:5 and 10:20f. in the context of the Pauline corpus. In 1 Corinthians 8:5a Paul asserts that there are entities that are called 'gods' by popular convention and usage, implying an understanding of the social phenomena of pagan worship. However, in verse $5 \mathrm{~b}$ Paul asserts the existence of the pagan gods as powers of evil, possibly personal beings in the supernatural/heavenly realm. The tentative conclusion that the 'gods' and 'lords' of 8:5b are evil powers is confirmed by 10:20-21 where the daimonia are personal supernatural evil beings. The daimonia may be tentatively classified under the rubric of the principalities and powers, the angels of the nations, and the spirits of the dead giants. Paul's view about evil powers is continuous with the beliefs found in Deuteronomy 32, Psalm 105(106), Zechariah 13, Tobit, Luke, 1 Enoch, Jubilees, and Revelation.

Chapter 6 focuses on the relationship between evil powers and idols in 1 Corinthians 10:18-22 in the context of the Pauline corpus. The relationship between daimonia and idols in Paul can be considered under the 'co-optative' view. First, the daimonia are powerful and enslave humanity into idolatry through humanity's evil inner inclination. By doing the will of the daimonia, idolaters serve them. Secondly, the daimonia deceive humanity into worshipping idols. Idols have a deceptive quality. The daimonia inspire idolatry, and possibly change their forms by disguising themselves as the pagan gods. Thirdly, the daimonia 'stand' or 'hide behind' the idols and co-opt and so appropriate for their own use the sacrifices consciously offered to the idols. The recognition and invocation of an idol brings the worshipper under the sphere of influence of daimonia because the daimonia divert the invocation or prayer intended for the idol.

This thesis does not find 'demythologisation' in Paul. It proposes a fresh approach for the scholarly debate, the 'co-optative' view, of the relationship between evil powers and idols in Paul. 